\title{
Body weight and water consumption in rats*
}

\author{
T. L. HOLDSTOCK \\ University of the Witwatersrand, Johannesburg, South Africa
}

\begin{abstract}
Lighter animals consumed more water than did heavier animals during ad lib drinking. This inverse relation between body weight and consumption was most apparent if the data were analyzed in terms of body weight. While on 23-and 47-h water deprivation, lighter rats drank more than heavier animals during the $1 \mathrm{~h}$ that water was available if their intakes were expressed in terms of body weight but not in absolute terms. The fact that animals consumed more water during the day than during the night was attributed to conditions of constant illumination that prevailed in the housing quarters.
\end{abstract}

Adolph (1949) demonstrated that larger mammals, such as the horse and elephant, drink, relative to their weight, less water per hour than smaller mammals, such as mice and rats. That this inverse relationship between body weight and water also holds within species has been suggested by Donovick and his group, working with rats (Donovick \& Burright, 1968; Donovick, Burright, \& Gittelson, 1968; Donovick, Burright, \& Gittelson, 1969). However, none of the three studies provide adequate proof of an inverse relation between body weight and water consumption in animals not brain-damaged. In addition, no consistent pattern of relationship between weight and various aspects of drinking behavior in normal and brain-damaged hooded rats was demonstrated in our own laboratory (Holdstock, Blesovsky, \& Verschoor, 1971). Since our experiment did not allow careful analysis of this problem, the present experiment was designed to investigate the relationship between body weight and water consumption within a more restricted weight range of a single species.

\section{METHOD}

Twenty-four male hooded rats, falling in six weight classes, were selected from stock cages in a constantly illuminated room. Each class consisted of four rats. The youngest and oldest animals were just under 3 months and over 5 months old, respectively. Upon removal from stock cages, the weight of the groups differed by $50 \mathrm{~g}$, with the lightest and heaviest groups weighing $200 \mathrm{~g}$ and $450 \mathrm{~g}$, respectively. Animals within each class had the same weight and were of the same age. After removal from stock cages, the rats were housed individually under constant lighting conditions with food available ad lib.

Measurement of water consumption began on the third day the animals were in individual cages. Measures were obtained twice daily, at 7:30 a.m. and 7:30 p.m., for 10 consecutive days by means of graduated $100-\mathrm{ml}$ pipettes. Ten days of $23-\mathrm{h}$ and four sessions of 47 -h water deprivation followed. During this time, the amount consumed during the hour that water was available in a heavy glass dish was measured at 11:00 a.m.

*This research was supported by a grant from the Human Sciences Research Council of South Africa.

\section{RESULTS}

Although the group weights differed initially by $50 \mathrm{~g}$, with no overlap between the groups, the lighter animals gained weight rapidly once they were in individual cages. Animals weighing $400 \mathrm{~g}$ and over maintained, but did not increase, their body weights (Fig. 1). This differential pattern of change in body weight was highly significant when weight on the initial and alternate days of ad lib water were subjected to a mixed design analysis



Fig. 1. Mean weight of the respective groups on different occasions during the experiment. Initial, day animals were placed in single cages; ad lib, last day of ad lib water; $23 \mathrm{~h}$, last day on 23-h water deprivation; $47 \mathrm{~h}$, last day on $47-\mathrm{h}$ water deprivation. 
Table 1

Analysis of Variance Values of Water Consumption Data Under Different Experimental Conditions

\begin{tabular}{|c|c|c|c|c|c|c|c|}
\hline \multicolumn{4}{|c|}{$\begin{array}{c}\text { Predeprivation: } 24 \text {-h Intake } \\
\text { Absolute Volume }\end{array}$} & \multicolumn{4}{|c|}{$\begin{array}{l}\text { Deprivation: 1-h Intake } \\
\text { Absolute Volume }\end{array}$} \\
\hline & $\mathrm{F}$ & df & $\mathrm{p}$ & & $\mathbf{F}$ & df & $\mathrm{p}$ \\
\hline $\begin{array}{l}\text { Group } \\
\text { Circadian }\end{array}$ & $\begin{array}{l}3.19 \\
6.35 \\
\end{array}$ & $\begin{array}{l}5,18 \\
1,18 \\
\end{array}$ & $\begin{array}{l}<.05 \\
<.05 \\
\end{array}$ & $\begin{array}{l}\text { Group } \\
24 \text { h vs } 47 \text { h }\end{array}$ & $\begin{array}{r}4.01 \\
52.18 \\
\end{array}$ & $\begin{array}{l}5,18 \\
1,18 \\
\end{array}$ & $\begin{array}{l}<.05 \\
<.001 \\
\end{array}$ \\
\hline \multicolumn{4}{|c|}{$\mathrm{ml} / 100 \mathrm{~g}$} & \multicolumn{4}{|c|}{$\mathrm{ml} / 100 \mathrm{~g}$} \\
\hline $\begin{array}{l}\text { Group } \\
\text { Circadian }\end{array}$ & $\begin{array}{r}29.68 \\
5.50\end{array}$ & $\begin{array}{l}5,18 \\
1,18\end{array}$ & $\begin{array}{l}<.001 \\
<.05\end{array}$ & $\begin{array}{l}\text { Group } \\
23 \mathrm{~h} \text { vs } 47 \mathrm{~h}\end{array}$ & $\begin{array}{r}4.55 \\
123.32 \\
\end{array}$ & $\begin{array}{l}5,18 \\
1,18 \\
\end{array}$ & $\begin{array}{l}<.05 \\
<.001\end{array}$ \\
\hline
\end{tabular}

of variance (Groups by Days: $F=2.45, \mathrm{df}=5 / 18$, $\mathrm{p}<.005)$. The groups also responded to deprivation by a differential pattern of weight loss. In this case, the heavier animals lost the most weight and the lighter rats the least (see Fig. 1). Analyzing the mean body weight during periods of ad lib drinking, 23- and 47-h water deprivation by means of a mixed design analysis of variance verified the differential weight change by the groups $(F=6.85, \mathrm{df}=10 / 36, \mathrm{p}<.001)$. Despite the convergence of group weights during the course of the experiment, hardly any overlap occurred, with the result that the group main effect was highly significant $(\mathrm{F}=$ 155.6, $\mathrm{df}=5 / 18, \mathrm{p}<.001)$.

The water consumption of the groups was analyzed in

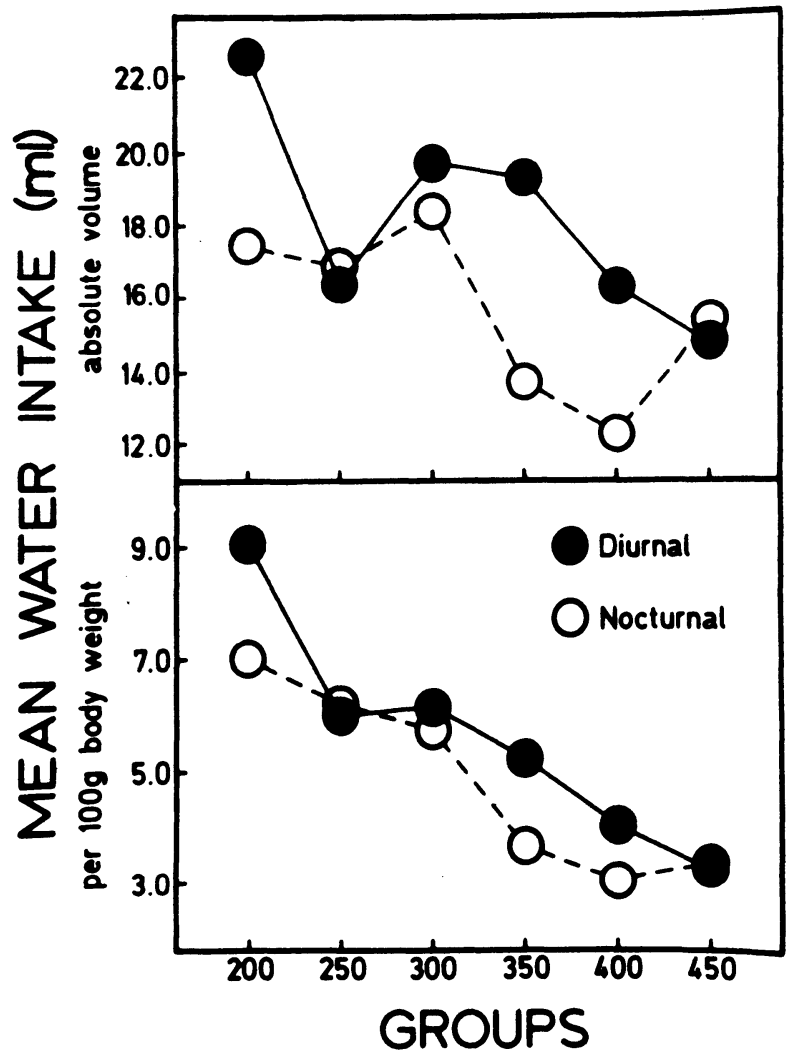

Fig. 2. Mean diurnal and nocturnal water intake expressed in absolute volume and volume $/ 100 \mathrm{~g}$ during the predeprivation period. terms of absolute amount and in terms of $100 \mathrm{~g}$ of body weight. Mixed analysis of variance was used to analyze the diurnal and nocturnal intake of the groups during the predeprivation period. The same analysis was applied to the deprivation data. In addition, between-group comparisons were made by means of Mann-Whitney U tests, while Spearman rank-order correlations were calculated between weight and absolute consumption and weight and volume/100 $\mathrm{g}$ for individual and grouped data.

The group main effect was found to be significant in absolute as well as in body weight terms for both 24-h intake and 1-h deprivation data (Table 1). The lighter groups consumed more water than did heavier animals in absolute amounts as well as per $100 \mathrm{~g}$ of body weight during the deprivation period (Fig. 2). However, the level of significance was much higher per $100 \mathrm{~g}$ of body weight than it was in absolute amounts. In addition, Mann-Whitney $U$ tests revealed that many more group comparisons were significant at the .05 level when dealing with volume/100 g (12 of 15$)$ than with absolute volume (3 of 15 ). During 23- and 47-h deprivation, the inverse relation between weight and water consumption held only when data were expressed in terms of body weight. In absolute amount, heavier animals drank the most water. Considerable overlap occurred in terms of the Mann-Whitney $U$ test between the respective groups on both absolute and volume/100 g measures. However, the fact that each group contained only four animals certainly influenced the value of $U$, for Spearman rank-order correlations presented in Table 2 generally support the inverse relation between body weight and volume $/ 100 \mathrm{~g}$, as well as the direct relation between body weight and absolute consumption during $1 \mathrm{~h}$ consumption.

Analysis of variance further revealed that the animals drank significantly more water during the day than during the night, both in absolute and in body weight terms (see Fig. 2 and Table 1). As is to be expected, considerably more water was consumed following $47 \cdot \mathrm{h}$ than following 23-h deprivation (Fig. 3 and Table 1).

\section{DISCUSSION}

In general, the results verified Adolph's (1949) finding of an inverse relation between body weight and water 
Table 2

Value of $\mathbf{r}_{\mathbf{S}}$ Between Weight and Consumption With Individual and Grouped Data

\begin{tabular}{|c|c|c|c|c|c|c|c|c|}
\hline \multirow[t]{3}{*}{ 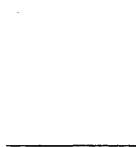 } & \multicolumn{4}{|c|}{ Predeprivation } & \multicolumn{4}{|c|}{ Deprivation } \\
\hline & \multicolumn{2}{|c|}{ Absolute Volume } & \multicolumn{2}{|c|}{$\mathrm{ml} / 100 \mathrm{~g}$} & \multicolumn{2}{|c|}{ Absolute Volume } & \multicolumn{2}{|c|}{$\mathrm{ml} / 100 \mathrm{~g}$} \\
\hline & Day & Night & Day & Night & $23 \mathrm{H}$ & $47 \mathrm{H}$ & $23 \mathrm{H}$ & $47 \mathrm{H}$ \\
\hline $\begin{array}{l}\text { Individual } \\
\text { Grouped }\end{array}$ & $\begin{array}{l}-0.48 * \\
-0.83\end{array}$ & $\begin{array}{l}-0.11 \\
-0.65\end{array}$ & $\begin{array}{l}-0.57 \dagger \\
-0.94 *\end{array}$ & $\begin{array}{l}-0.71^{*} \\
-0.94\end{array}$ & $\begin{array}{l}0.54 * \\
0.54\end{array}$ & $\begin{array}{c}0.62 \div \\
-0.54\end{array}$ & $\begin{array}{l}-0.81 \div \\
-0.94 *\end{array}$ & $\begin{array}{l}-0.39 \\
-0.94 *\end{array}$ \\
\hline
\end{tabular}

${ }^{*} p<.05 \quad t p<.01$

intake obtained across species, within the narrower weight ranges of a single species. However, it was apparent that this relationship was influenced by a number of variables. It was most evident if the data were analyzed in terms of $100 \mathrm{~g}$ of body weight. Deprivation conditions, and especially 47-h deprivation, also affected the relation between consumption and body weight. Analyzed in terms of absolute volume, a significant positive correlation existed between weight and volume, while negative correlations were obtained per $100 \mathrm{~g}$ of body weight. Just why heavy rats drank less than lighter ones under ad lib conditions and not while on deprivation is not clear at this stage.

It is reasonable to assume that the greater consumption of the lightest animals was due to the fact that they were the youngest and still in the process of growing. However, it is doubtful that age differences offer a complete explanation, for the discrepancy in consumption was also apparent between adult groups differing in weight. For instance, the $300-\mathrm{g}$ group differed from the $350-\mathrm{g}(\mathrm{U}=1, \mathrm{p}=.058$, two-tailed $)$ and the 400 -g groups $(U=0, p=.028$, two-tailed $)$ in terms of body weight.

Contrary to expectations, the animals drank more water during the day than during the night. In a sense, this finding is related to a previous report from our laboratory, that rats housed in constant illumination lapped with a much greater frequency during the daily drinkometer period than did animals maintained under natural day-night lighting (Holdstock et al, 1972). These results seem to be explained most meaningfully if it is assumed that constant illumination has the same effect as early blinding and congenital blindness of freeing the circadian clock from a fixed starting time so that the inborn 12-h activity cycle in the rat drifts out of phase with the lighting cycle (Richter, 1971) and eventually comes to be displaced towards the day. If the clock were truly free running, one would expect that the period of maximal ingestion would eventually shift back towards the night.

\section{REFERENCES}

Adolph, E. F. Quantitative relations in the physiological constitutions of mammals. Science, 1949, 109, 579-585.

Donovick, P. J., \& Burright, R. G. Water consumption of rats

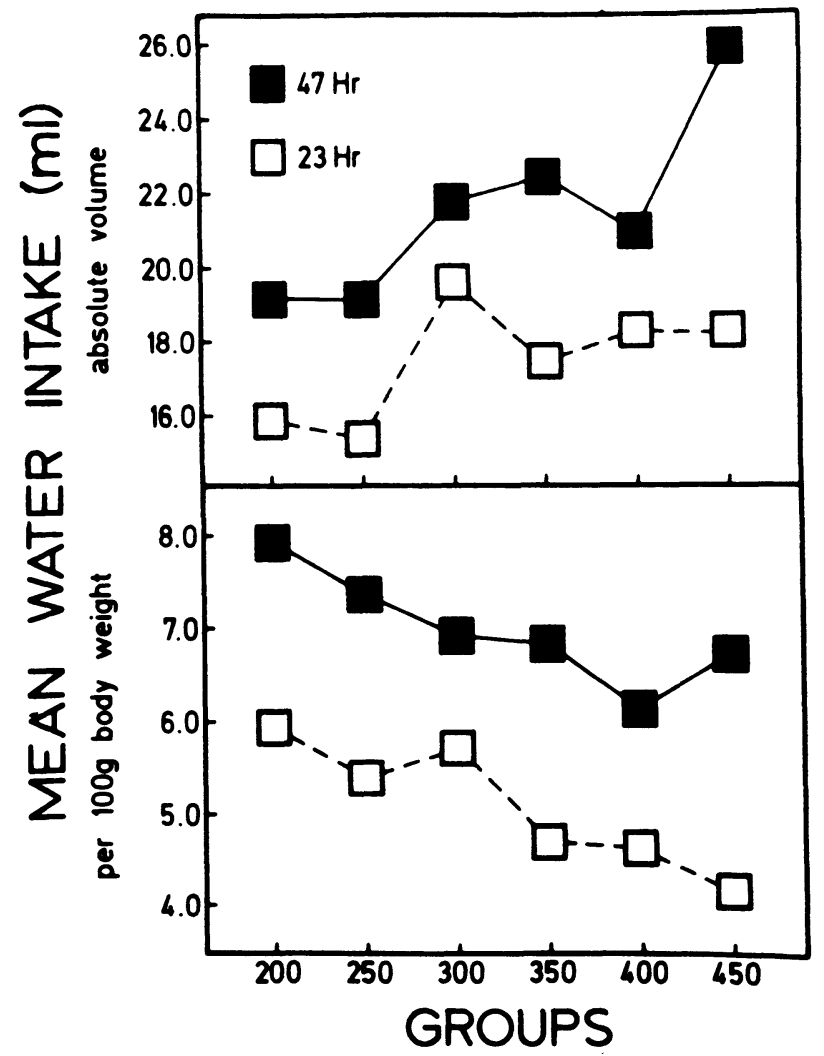

Fig. 3. Mean 1-h water intake expressed in absolute volume and in volume $/ 100 \mathrm{~g}$ during schedules of $23-$ and $47-\mathrm{h}$ water deprivation.

with septal lesions following two days of water deprivation. Physiology \& Behavior, 1968, 3, 285-288.

Donovick, P. J., Burright, R. G., \& Gittelson, P. J. The effects of septal lesions on saccharine choice as a function of water deprivation. Physiology \& Behavior, 1968, 3, 677-681.

Donovick, P. J., Burright, R. G., \& Gittelson, P. L. Bodyweight and food and water consumption in septal lesioned and operated control rats. Psychological Reports, 1969, 25, 303-310.

Holdstock, T. L., Blesovsky, L. T., \& Verschoor, G. J. Effect of home cage lighting on drinking behavior of rats with septal lesions. Physiology \& Behavior, 1972, 8, 847-851.

Richter, C. P. Inborn nature of the rat's 24-hour clock. Journal of Comparative \& Physiological Psychology, 1971, 75, 1-4.

(Received for publication June 26, 1972; revision received August 21, 1972.) 